J. Clin. Chem. Clin. Biochem.

Vol. 17, 1979, pp. 693-704

\title{
Clinical Aspects of Gut Enzymology ${ }^{1}$ )
}

\author{
By Ellen Schmidt and F. W. Schmidt
}

Abt. f. Gastroenterologie und Hepatologie, Medizinische Hochschule Hannover

(Received May 2/September 7, 1979)

\section{In memoriam Gábor Szász}

Summary: Enzymological alterations in functional disturbances and in diseases of the intestine are reviewed. Examples are given for diagnostic significance (e.g. in Hirschsprung's and Crohn's diseases), for pathogenetic considerations (e.g. in hypolactasia and in celiac disease), and for secondary involvement of the liver (e.g. in intestinal tumors and after bypass surgery) and are discussed in more detail.

\section{Klinische Aspekte der Enzymologie des Darms}

Zusammenfassung: Enzymologische Veränderungen bei Funktions-Störungen und Erkrankungen des Darmes werden anhand der neueren Literatur dargestellt und an einzelnen Krankheitsbildern näher beschrieben: diagnostische Bedeutung (z.B. beim M. Hirschsprung und M. Crohn), pathogenetische Aspekte (z.B. bei der Hypolactasie und der Coeliakie), sowie Folgeerscheinungen an der Leber (z.B. bei Darm-Tumoren und nach Bypass-Operationen) werden besprochen.

\section{Introduction}

When discussing the pathology of intestinal enzymes, it is commonplace to begin with the enzyme deficiencies, although they are actually rather rare disorders. For the clinician, they are less important than the ordinary bowel diseases and their enzymological aspects.

\section{Constipation}

In temperate industrialized countries, constipation is the most common disorder of the gut in the adult. Unfortunately, as a rule, neither morphological nor biochemical findings correlate with the impaired bowel motility. More often than not, it must be attributed to dietary and emptying habits or to psychosomatic origins.

There is, however, one important exception, well known to the pediatrician: Hirschsprung's disease. Its diagnosis relies on radiology, manometry and essentially on the absence of ganglion cells in biopsies of rectal submucosa, which is difficult to demonstrate. The discovery of an increased acetylcholinesterase activity in rectal tissue contributed a great deal more precision to the diagnosis. Initially, histochemical detection was employed $(1,2,3)$, the

\footnotetext{
1) Partly presented as Invited Lecture at the 2nd Meeting of the International Society for Clinical Enzymology, 25.2.-2.3.1979, San Diego, Cal. USA.
}

results being somewhat subjective and, at best, semiquantitative (4). A more accurate biochemical method, measured in homogenate, was introduced by Boston et al. in 1975 (5) and was improved by the use of a selective inhibitor of non-specific cholinesterases (6). Acetylcholinesterase, expressed as fraction of total cholinesterase is about twice as high in biopsies obtained from patients with Hirschsprung's disease than in normal rectal biopsies. Figure 1 shows that the borderline lies between 0.60 and 0.70 and that there is no overlap.

Recently, Boston et al. found a similar difference in serum and in red blood cells, but here the overlap is considerable. This is, nonetheless, an interesting sign of the systemic effects of Hirschsprung's disease (7).

\section{Diarrhea}

In children, in wärm climates, and in developing countries, diarrhea is more common than constipation. In addition, episodes of loose stools alternating with constipation belong to the irritable bowel syndrome in the adult.

The various causes of acute and chronic diarrhea can thus be grouped primarily as infectious and presumably noninfectious, and the latter further into socalled functional diarrhea, which is used synonymous to psychogenic, and 


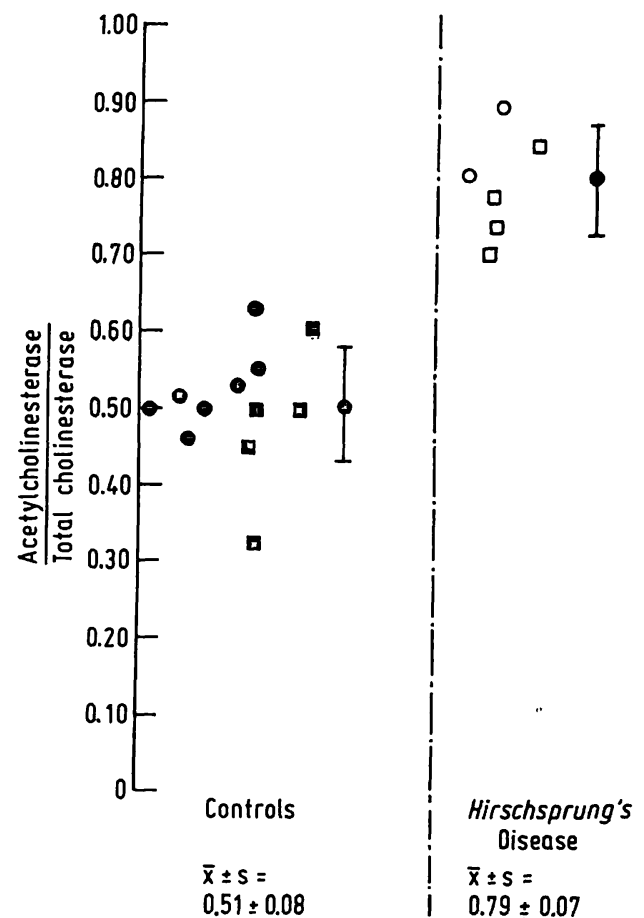

Fig. 1. Acetylcholinesterase as fraction of total cholinesterase activity (from Dale et al. (6)).

the primary metabolic type, which is due to a deficiency or insufficiency in digestion or absorption. Differential diagnosis between these basically different etiologies is not as easy as might be imagined.

Table 1 demonstrates that the main abdominal symptoms are virtually the same in lactose intolerance and in the irritable colon syndrome (8). Thuș, it is not too surprising to find, among patients with non-specific abdominal complaints, some with metabolic disturbances, which are often falsely diagnosed for years (table 2 ; $8,9,10)$. In this group, hypolactasia is naturally the most

Tab. 1. Incidence of abdominal symptoms in patients with unspecific abdominal complaints (from Jussila et al. (8)).

\begin{tabular}{lcl}
\hline Jejunal lactașe activity & $\begin{array}{l}>1.5 \mathrm{U} / \mathrm{g} \\
(\mathrm{n}=29)\end{array}$ & $\begin{array}{l}<1.5 \mathrm{U} / \mathrm{g} \\
(\mathrm{n}=12)\end{array}$ \\
\hline Abudominal fullness & $100 \%$ & $92 \%$ \\
Meteorișm & $76 \%$ & $83 \%$ \\
Nausea & $55 \%$ & $50 \%$ \\
Unidentified abdominal complaints & $45 \%$ & $42 \%$ \\
Loose stools & $38 \%$ & $42 \%$ \\
Watery diarrhea & $14 \%$ & $25 \%$ \\
Obstipation & $17 \%$ & $8 \%$ \\
\hline
\end{tabular}

Tab. 2. Lactase activity in jejunal biopsies of patients with irritable colon syndrome (from Weser et al. (9)).

n Lactase . Saccharase (U/g protein) (U/g protein)

Patients with irritable gut and normal lactose tolerance Patients with irritable gut

and aḅnọmal lactose tolerance $1 \quad 4 \quad 3.9 \pm 3.1 \quad 39.6 \pm 11.5$ Patients with untreated celiac disease

Asymptomatic controls
$6 \quad 34.0 \pm 11.9 \quad 45.1 \pm 22.8$

$9 \quad 2.9 \pm 1.7 \quad 21.8 \pm 15.0$ $5 \quad 49.6 \pm 17.5 \quad 67.3 \pm 24.6$
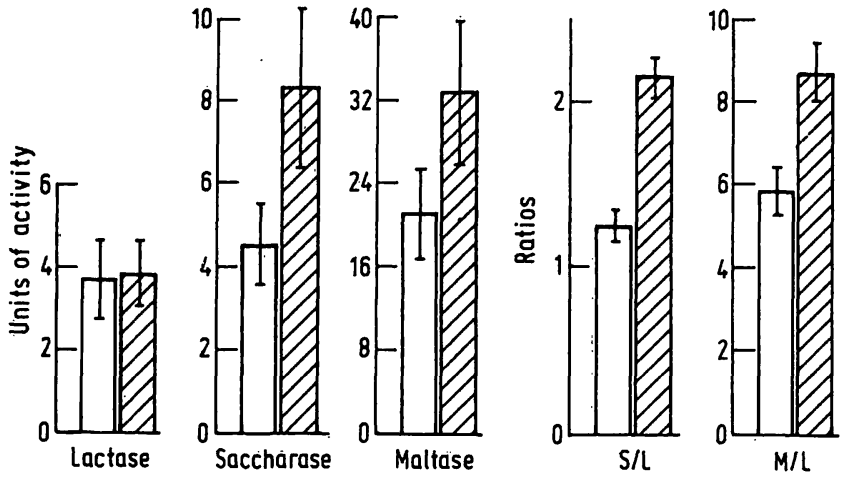

Fig. 2. Mean disaccharidase activities and saccharase - tolactase $(\mathrm{S} / \mathrm{L})$ and maltase-to-lactase $(\mathrm{M} / \mathrm{L})$ ratios in one normal subject on glucose (white columns) and fructose (hatched columns) diets. The standard error of the mean is in brackets. From Rosensweig (16).

common event, ranging from $30-50 \%(8,9)$. True deficiencies, however, which should also be considered are fructose malabsorption (10), saccharose-isomaltose malabsorption $(11,12,13)$, glucose-galactose malabsorption $(14,15)$ and other even rarer deficiencies. The importance of their detection lies in the therapeutical consequences: long-standing diarrhea and abdominal distress can be cured within days by a diet which avoids the malabsorbed carbohydrate or induces the defective enzyme without adverse side-effects, as e.g. the nonsubstrate fructose does in incomplete saccharase deficiency (fig. 2; 16,17).

Not only brush border enzymes such as the disaccharidases, but also cytosolic enzymes of intermediary carbohydrate metabolism, adapt to dietary sugars. Folate plays a role in this regulation, which is still poorly understoogd, and, besides the overall adaptation to a carbohydrate-rich diet, specific reactions of single enzymes to individual sugars occur. When these essential regulatory processes are disturbed, similar symptoms as in malabsorption of sugars ensue. Such observations led Rosensweig and his group to the concept of the "maladaptation syndrome" in cases of carbohydrate-sensitive diarrhea without overt enzyme deficiency or any other gastro-intestinal disorder $(16,18)$.

Some remarks on hypolactasia, which is a more adequate term than lactase deficiency for the denotation of the normal developmental pattern in mammals, the decrease of lactase after weaning: in the human, hypolactasia is also the "wild type" in genetic language, and the prevailing condition of adult age in most populations. Table 3 shows that persistent lactase activity is common in Northern and Central Europe and in the white population of North America and Australia, particularly in their fair-complexioned part. Persistent lactase activity is very rare or absent in most Mongolian populations, including Indians and Eskimos, in tropical Africa and in the Melanesian peoples. With few exceptions, it is rare in the Middle East. In between, there is a broad zone in Southern Europe with 30-70\% persistent lactase activity (19): 
Tab. 3. Geographical distribution of lactase phenotypes and persistent lactase activity (PLA) gene frequency (from Flatz \& Rotthauwe (19)).

\begin{tabular}{|c|c|c|c|c|c|}
\hline $\begin{array}{l}\text { Country } \\
\text { or region }\end{array}$ & $\begin{array}{l}\text { Group } \\
\text { or location }\end{array}$ & $\begin{array}{l}\text { Number } \\
\text { examined }\end{array}$ & $\begin{array}{l}\text { Number } \\
\text { of absorbers }\end{array}$ & $\begin{array}{l}\text { Number } \\
\text { of malabsorbers }\end{array}$ & $\begin{array}{l}\text { Frequency } \\
\text { of PLA gene }\end{array}$ \\
\hline $\begin{array}{l}\text { Sweden } \\
\text { Denmiark } \\
\text { Germariy } \\
\text { Spain } \\
\text { CSSR } \\
\text { Greece }\end{array}$ & $\begin{array}{l}\text { Patients } \\
\text { Patierits } \\
- \\
- \\
\text { Czechs } \\
\text { Greeks }\end{array}$ & $\begin{array}{r}700 \\
155 \\
67 \\
267 \\
104 \\
700\end{array}$ & $\begin{array}{r}679 \\
139 \\
59 \\
209 \\
76 \\
371\end{array}$ & $\begin{array}{r}21 \\
16 \\
8 \\
58 \\
28 \\
329\end{array}$ & $\begin{array}{l}0.827 \\
0.679 \\
0.654 \\
0.534 \\
0.481 \\
0.341\end{array}$ \\
\hline $\begin{array}{l}\text { Pakistan } \\
\text { India } \\
\text { Israel } \\
\text { Lebanon } \\
\text { Thailand } \\
\text { USA }\end{array}$ & $\begin{array}{l}\overline{\text { Delhi }} \\
\text { - } \\
\text { Arabs } \\
\text { North } \\
\text { Whites } \\
\text { Indians } \\
\text { Negroes } \\
\text { Eskimos } \\
\text { - }\end{array}$ & $\begin{array}{r}55 \\
70 \\
93 \\
151 \\
149 \\
771 \\
75 \\
349 \\
36 \\
60\end{array}$ & $\begin{array}{r}52 \\
50 \\
36 \\
32 \\
0 \\
592 \\
26 \\
76 \\
6 \\
0\end{array}$ & $\begin{array}{r}3 \\
20 \\
57 \\
119 \\
149 \\
179 \\
49 \\
273 \\
30 \\
60\end{array}$ & $\begin{array}{l}0.766 \\
0.465 \\
0.217 \\
0.112 \\
0 \\
0.518 \\
0.192 \\
0.116 \\
0.087 \\
0\end{array}$ \\
\hline
\end{tabular}

Origin and significance of persistent lactase activity are still under discussion. The persistent lactase activity gene must certainly have emerged by mutation and spread as a consequence of a selective advantage. The cultural historic hypothesis $(20,21)$ states that after the domestication of milking animals in the Neolithic age, some population groups learned to ferment milk, while others did not, and developed persistent lactase activity. This theory probably fits small groups of nomads under extreme conditions. The map of the world, however, shows no parallelism between milk drinkers and persistent lactase activity. This, and elaborate calculations of CavalliSforza (22), rule out dairy farming as a general cause of lactase persistence.

There must then be a selective advantage for the lactose absorber in higher latitudes: Flatz \& Rotthauwe put forward a hypothesis (23) that, due to its promotion of calcium absorption, lactose can replace vitamin $D$ in restoring calcium balance in rickets $(24,25)$, and analogous to the depigmentation of the Northern Europeans, good lactose absorption would prevent rickets, particularly pelvis deformation in young women, and could thus favor the propagation of individuals with persistent lactase activity in environments with low UV irradiation and poor dietary supply of vitamin $D(26,27)$.

This theory is also not unchallenged $(28,29)$, and many other more practical problems are still open concerning the two lactase phenotypes: aside from the question of the usefulness of "milk programs" in countries with a high incidence of non-absorbers and in milky diets for nutritional restoration in general, primary hypolactasia frequently interferes with the diagnostic procedure in secondary disaccharidase deficiencies, which are very common and arise from a wide variety of causes.

This can be demonstrated by comparing disaccharidase activity in jejunal biopsies from black and caucasian american alcoholics: in the former group with the high
Tab. 4. Symptomatic intestinal disaccharidase deficiency in alcoholics (from Perlow et al. (30)).

\begin{tabular}{lcc}
\hline & $\begin{array}{l}\text { Lactase activity } \\
<1 \mathrm{U} / \mathrm{g}\end{array}$ & $\begin{array}{l}\text { Saccharase } \\
\text { activity } \\
<6 \mathrm{U} / \mathrm{g}\end{array}$ \\
\hline White controls & $0 / 7$ & $0 / 6$ \\
White alcoholics & $2 / 12$ & $2 / 8$ \\
Black controls & $5 / 10$ & $0 / 7$ \\
Black alcoholics & $11 / 11$ & $3 / 7$ \\
\hline
\end{tabular}

rate of non-absorbers, the alcohol-induced mucosal atrophy apparently leads to lactase deficiency in all cases, but only in 3 cases to a parallel decrease in saccharase activity, whereas in the white group the alterations of both enzymes correlate well (table $4 ; 30$ ). The correlation between the diminution of brush border enzymes, such as disaccharidases and oligopeptidases and of cytosolic enzymes, such as dipeptidases and their respective amount in normal enterocytes on the one hand, and the degree of mucosal atrophy on the other, as is shown in figure 3, holds also true for lactase, but only in populations with a high prevalence of persistent lactase activity $(31,32,32 a)$.

Celiac disease is a good example both of this parallelism and of the reversibility of the pathological changes with adequate dietary therapy (table $5 ; 33,34$ ). The diminution of brush border enzymes precedes the respective alterations of the cytosolic enzymes, which may not be marked until mucosal atrophy is total (fig. $4 ; 33,34,35$ ). Meanwhile there is a considerable increase of lysosomal enzymes in mucosal tissue, which has for reasons of quantity been attributed to the enterocytes themselves, not to the infiltrating round cells, and which is combined with an augmented lysosomal fragility (fig. 5; 36,37).

After gluten withdrawal from the diet, nearly all the enzymes return to normal and the stability of the 


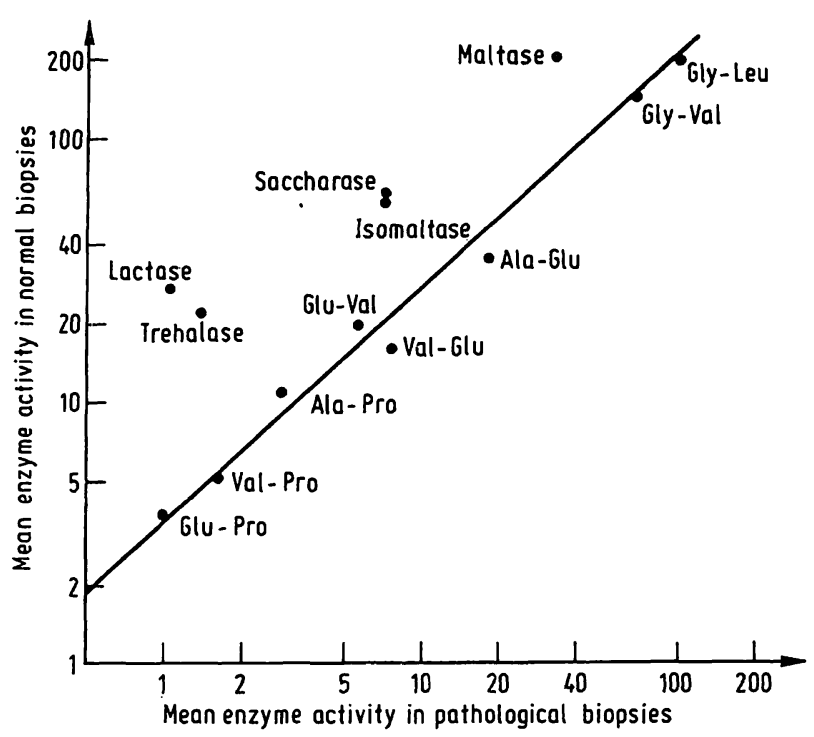

Fig. 3. Log-log diagram of enzyme activities in normal and pathological mucosa in intestinal biopsies. Disaccharidase activities are expressed as units/g protein and dipeptidase activities (enzymes indicated by their substrates) as units/ $\mathrm{mg}$ N. From Berg et al. (31). subcellular organelles improves. Only the defectiveness of the brush border enzymes persists, despite the quite normal morphology found after $2-10$ years of treatment (37). Phlorizin hydrolase, a brush border $\beta$ glucosidase, in particular remains very low or absent. This has led to consideration of an etiological role of this enzyme in glutensensitive enteropathy; the more so since a carbohydrate component of gliadine is probably the noxious part of wheat flour which cannot be degraded and binds to the brush border as the primary site of impact $(38,39,40,41)$.

Rather unaffected in celiac disease remains the enterokinase (table 6 ; 42,43). This and other evidence has led to the conclusion that enterokinase is not a brush border enzyme but a secretory enzyme which originates in the Brunner glands or the goblet cells $(44,45,46,47)$, which are scarcely involved in the atrophy in celiac disease.

There are, however, conditions with subtotal reduction of enterokinase activity in duodenal mucosa with grade III atrophy, clinically appearing as intractable diarrhea of infancy $(45,49,50)$. Figure 6 demonstrates the difference

Tab. 5. Reversibility of the pathological changes in the disaccharidase activities $(\overline{\mathrm{X}} \pm \mathrm{SD})$ with adequate dietary therapy (from Malis et al. (33)).

\begin{tabular}{|c|c|c|c|c|c|c|}
\hline Adults & No. & $\begin{array}{l}\text { Saccharase } \\
\text { (U/g protein) }\end{array}$ & $\begin{array}{l}\text { Maltase } \\
\text { (U/g protein) }\end{array}$ & $\begin{array}{l}\text { Trehalase } \\
\text { (U/g protein) }\end{array}$ & $\begin{array}{l}\text { Lactase } \\
\text { (U/g protein) }\end{array}$ & $\begin{array}{l}\text { Cellobiase } \\
\text { (U/g protein) }\end{array}$ \\
\hline $\begin{array}{l}\text { Control group } \\
\text { Celiac sprue }\end{array}$ & 15 & $148.0 \pm 10.5$ & $443.0 \pm 44.9$ & $33.3 \pm 3.5$ & $48.4 \pm 5.2$ & $12.6 \pm 1.3$ \\
\hline $\begin{array}{l}\text {-relapse } \\
\text {-remission }\end{array}$ & $\begin{array}{r}9 \\
14\end{array}$ & $\begin{array}{l}13.3 \pm \quad 4.9 \\
59.2 \pm 18.8\end{array}$ & $\begin{array}{rc}37.3 \pm & 11.2 \\
177.0 & \pm 38.0\end{array}$ & $\begin{array}{r}0.5 \pm 0.2 \\
14.6 \pm 3.3\end{array}$ & $\begin{array}{r}1.5 \pm 0.9 \\
15.1 \pm 3.8\end{array}$ & $\begin{array}{l}0.7 \pm 0.3 \\
3.2 \pm 1.6\end{array}$ \\
\hline \multicolumn{7}{|l|}{ Children } \\
\hline $\begin{array}{l}\text { Control group } \\
\text { Celiac sprue }\end{array}$ & 17 & $176.8 \pm 25.9$ & $524.5 \pm 81.0$ & $28.5 \pm 4.9$ & $48.8 \pm 6.8$ & $15.2 \pm 2.7$ \\
\hline $\begin{array}{c}\text {-relapse } \\
\text {-remission } \\
\text { Mucoviscidosis }\end{array}$ & $\begin{array}{r}27 \\
25 \\
8\end{array}$ & $\begin{array}{r}22.8 \pm 3.7 \\
87.0 \pm 15.1 \\
119.5 \pm 40.0\end{array}$ & $\begin{array}{r}62.9 \pm \quad 6.9 \\
221.0 \pm 40.5 \\
332.4 \pm 130.0\end{array}$ & $\begin{array}{r}1.0 \pm 0.2 \\
10.9 \pm 3.3 \\
7.5 \pm 2.5\end{array}$ & $\begin{array}{r}1.6 \pm 0.6 \\
15.9 \pm 3.6 \\
28.5 \pm 8.2\end{array}$ & $\begin{array}{l}0.6 \pm 0.2 \\
5.1 \pm 1.0 \\
7.6 \pm 2.2\end{array}$ \\
\hline
\end{tabular}
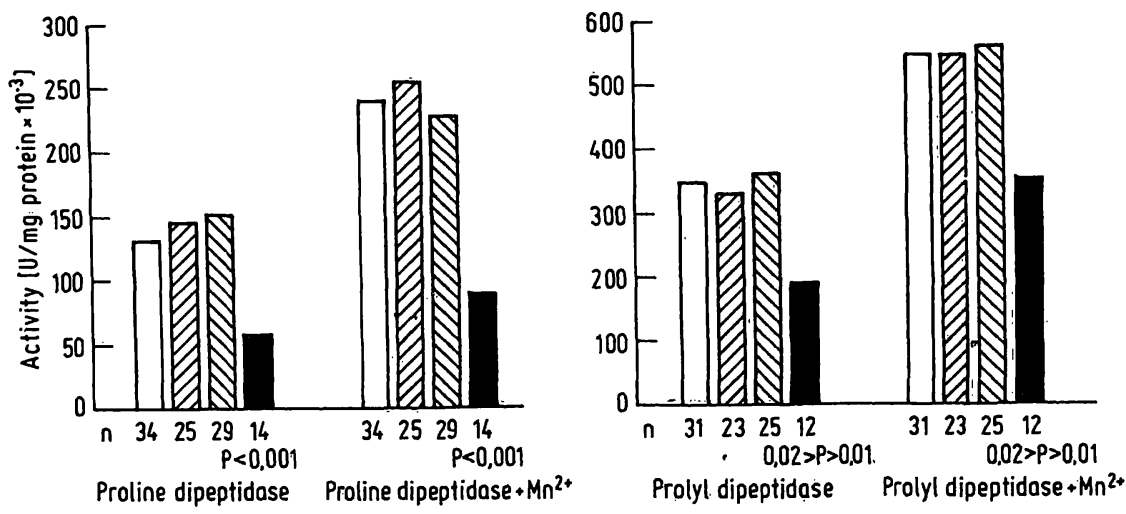

Fig. 4. Activity of proline dipeptidase and prolyl dipeptidase in small intestinal mucosa homogenates from normal children and those suffering from different degrees of villous damage. From Grävinghoff \& Hütter (34). . 


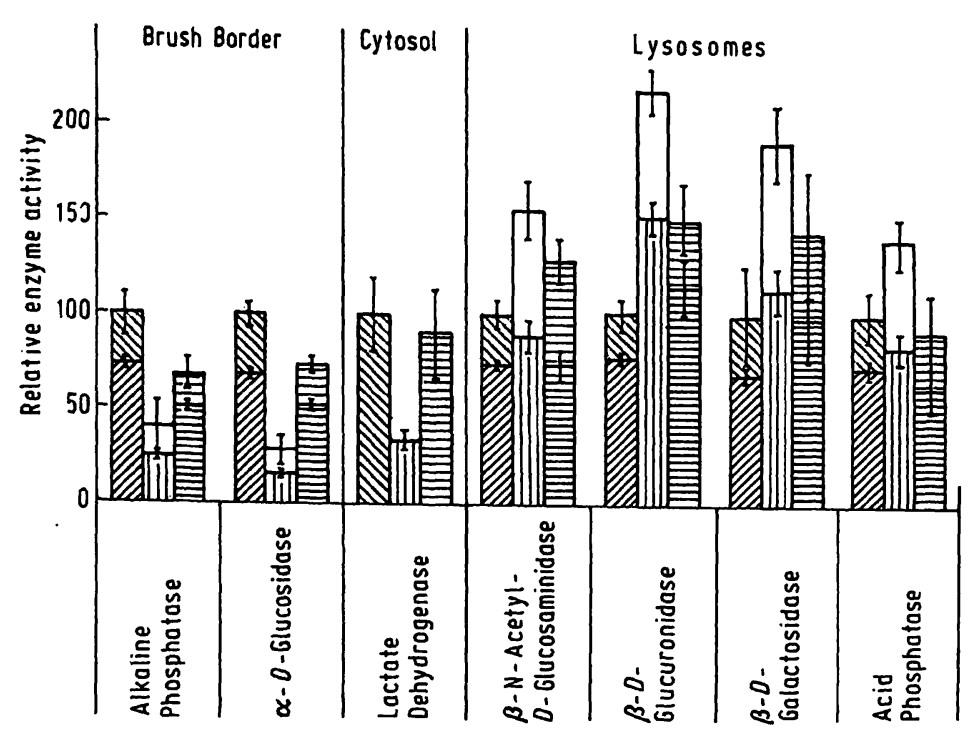

Fig. 5. Enzyme activitics in jejunal biopsies from control subjects $(=100)$ and patients with celiac disease. First column: normal jejunum; second column: celiac disease untreated; third column: celiac disease treated. Lower part of columns: sedimentable portion. From Peters et al. (36).

Tab. 6. Enterokinase activity in various diseases of the intestine (from Niessen et al. (44)).

\begin{tabular}{lrrr}
\hline & $\begin{array}{c}\text { No. of } \\
\text { biop- } \\
\text { sies }\end{array}$ & Mucosal & Intraluminal \\
\hline $\begin{array}{l}\text { Control, normal } \\
\text { mucosa }\end{array}$ & 59 & $109.0 \pm 34.2$ & $18.6 \pm 8.8$ \\
$\begin{array}{l}\text { Chronic nonspecific } \\
\text { diarrhea }\end{array}$ & & & \\
$\quad \begin{array}{c}\text { Atrophy grade I } \\
\text { Atrophy grade II }\end{array}$ & 30 & $61.7 \pm 44.2$ & $12.9 \pm 3.7$ \\
$\begin{array}{l}\text { Milk protein allergy } \\
\text { Hypoproteinemia }\end{array}$ & 6 & $44.4 \pm 27.0$ & $10.6 \pm 5.7$ \\
$\begin{array}{l}\text { Intestinal lymphan- } \\
\text { giectasia }\end{array}$ & 4 & $79.1 \pm 35.0$ & $12.5 \pm 2.0$ \\
$\begin{array}{l}\text { Lymphoid nodular } \\
\text { hyperplasia }\end{array}$ & 3 & $83.2 \pm 23.3$ & $12.3 \pm 0.4$ \\
$\begin{array}{l}\text { Saccharase-isomaltase } \\
\text { deficiency }\end{array}$ & 3 & $105.6 \pm 23.3$ & $18.2 \pm 1.3$ \\
$\begin{array}{c}\text { Low tryptic activity } \\
\text { Cystic fibrosis }\end{array}$ & 9 & $92.8 \pm 38.0$ & $87.6 \pm 30.3$ \\
$\begin{array}{l}\text { Shwachman-diamond } \\
\text { syndrome }\end{array}$ & 3 & $91.9 \pm 18.6$ & $30.0 \pm 8.3$ \\
$\begin{array}{l}\text { Congenital enterokinase } \\
\text { deficiency }\end{array}$ & 2 & 0 & 0 \\
\hline
\end{tabular}

between celiac disease and intractable diarrhea with respect to enterokinase and the similarity with respect to the disaccharidàses. Thus, a pathogenetic role of enterokinase has been discussed, related possibly to a reduced number of goblet cells or to the effect of impaired output of bile acids or as primary enterokinase deficiency $(44,45,48,51)$.

On the whole, there are still many inconsistencies in the findings of different authors in non-infectious diarrheal disorders, particularly with regard to etiological factors and immunological processes $(52,53,54)$. The clinical and

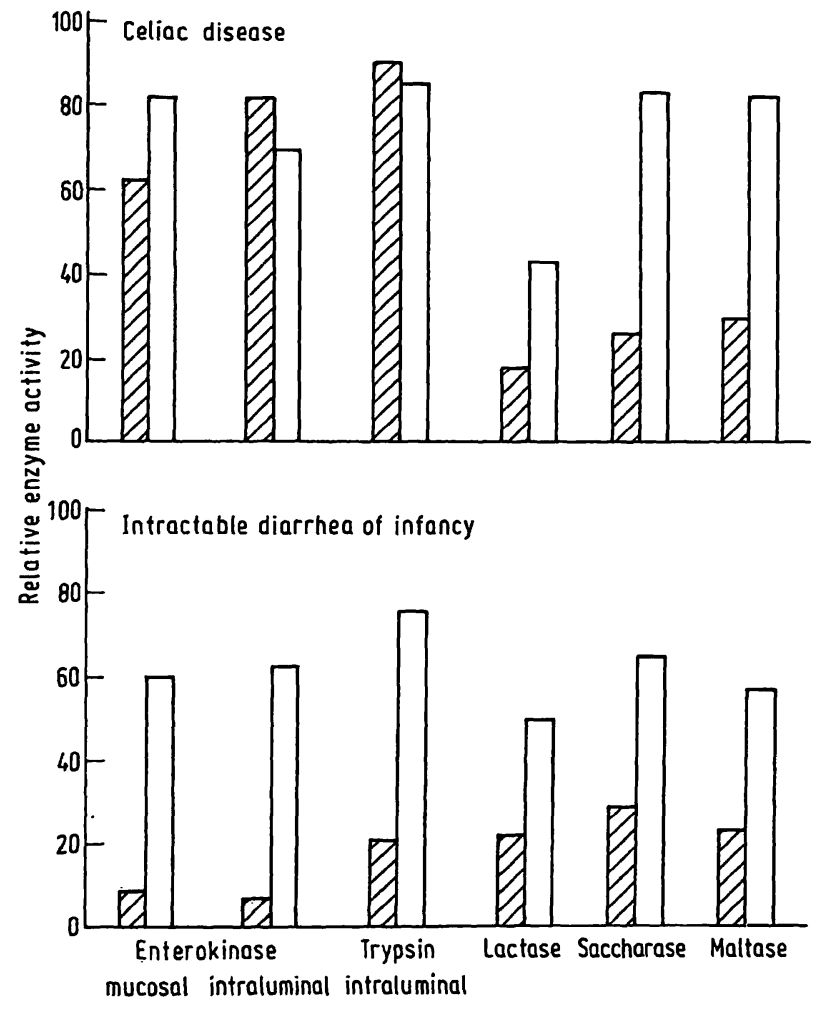

Fig. 6. Relative enzyme activity (normal $=100$ ) in untreated (hatched columns) and treated (open columns) celiac disease and intractable diarrhea of infancy. From Lebenthal et al. (45).

the enzymological picture becomes even more complicated by the intestinal sequelae of exocrine pancreatic insufficiency.

In infancy, cystic fibrosis, and in adult age, the various types of chronic pancreatitis must be differentiated from primary enteropathies. As long as the intestinal mucosa 

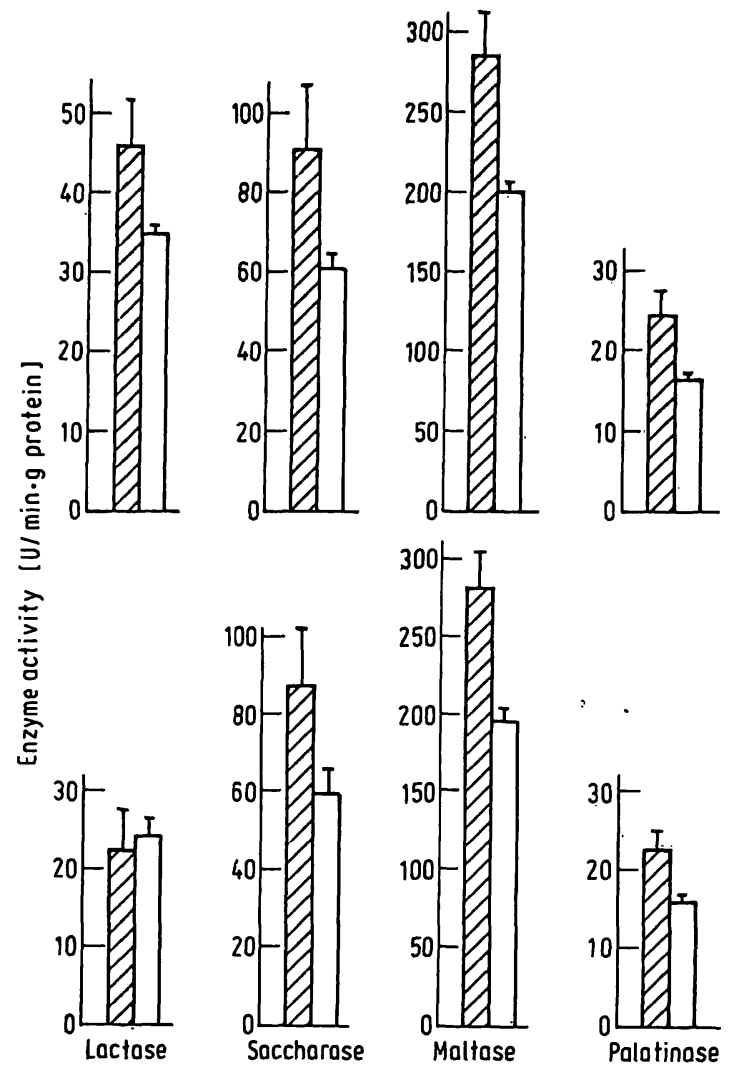

Fig. 7. Comparison of the disaccharidase activities in patients with cystic fibrosis (hatched columns) and in control subjects (white columns) with normal morphology. Upper part of figure represents groups under 5 years of age (134 controls, 21 patients) and lower part, groups above 5 years of age ( 43 controls, 15 patients). From Arvantakis $\&$ Olsen (56). Vertical lines represent \pm SEM.

is not involved, chronic pancreatic insufficiency leads to elevated instead of decreased activities of brush border enzymes, suggesting delayed proteolytic degradation (fig. $7 ; 33,55,56,57$ ).

\section{Inflammatory Disorders}

The disturbance of lactose absorption in acute enteritis is long known. It is due to a transient villous atrophy with low disaccharidase, particularly lactase, activity. The evidence that lactase is the enzyme most vulnerable in gastrointestinal infections and in malnutrition $(58,59,60$, 61 ) has led to the hypothesis of lactose intolerance in tropical countries as being secondary to mucosal damage in childhood $(62,63)$. This was later rejected by other investigators $(16,19)$. It is, however, understandable that chronic inflammatory bowel disease, such as ulcerative colitis and Crohn's disease, also have reduced activities of disaccharidases, at least during acute stages $(64,65,66)$.

The etiology and pathogenesis of ulcerative colitis and Crohn's disease are still obscure and the differential diagnosis between them often difficult. Since Crohn's disease is a granulomatous inflammation, several enzymes known to be elevated in other granulomatous diseases have been tested in this respect. Collagen peptid-

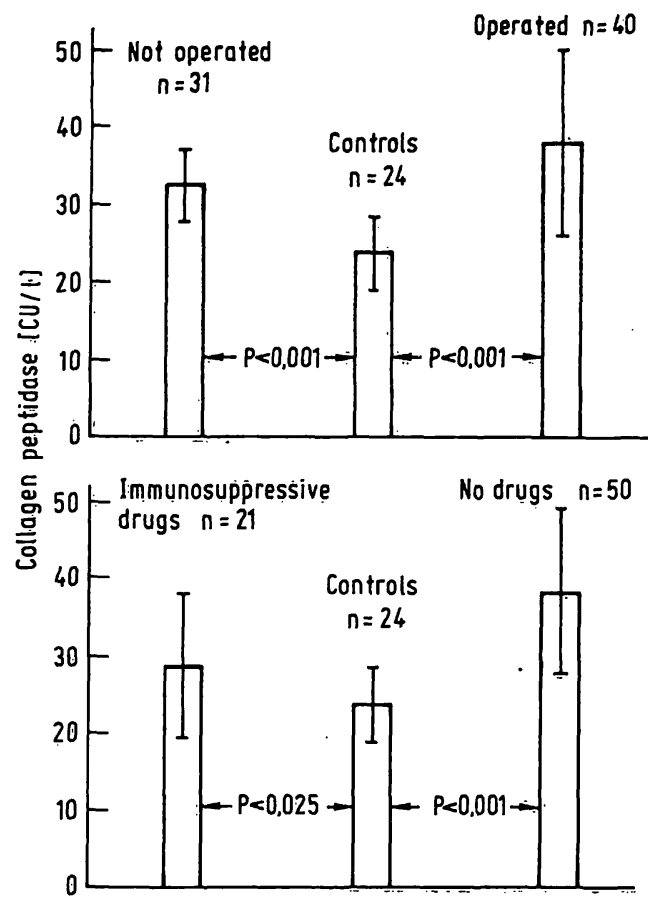

Fig. 8. Collagen peptidase activity in serum in Crohn's disease. From Shalev et ạl. (67).

ase was found to be elevated in serum in regional enterocolitis (fig. 8; 67). Its activity has been found higher in more severely ill patients, and lower under immunosuppressive treatment. It is likewise elevated, however, in rectal mucosa of patients with ulcerative colitis (68). Thus, it is probably only a non-specific marker of inflammatory processes.

Glucosamine synthetase, a possibly rate-limiting enżyme of glycoprotein synthesis, has been measured in colonic biopsies from patients with ulcerative and membranous colitis and with Crohn's disease $(69,70)$. It was found to be correlated to the density of enterocytes and was thought to be indicative of the healing capacity of the mucosa. No difference was found among the 3 disorders. Recently, a highly significant increase of prolyl hydroxylase in rectal mucosa of patients with Crohn's disease, but not with ulcerative colitis, has been reported by Farthing et al. (71). The 3-fold increase of this enzyme of collagen metabolism in the unaffected rectal mucosa of Crohn patients provides further evidence for the diffuse nature of regional enterocolitis. However, whether this enzyme can serve for differential diagnosis should be judged with caution: There is a broad overlap, and the experience with the determination of lysozzyme, initiated with such great expectations, might be a warning. The suggestion by Falchuk et al, that differential diagnosis of inflammatory bowel diseases is possible by the determination of lysożyme in serum (72), has, to date, not produced convincing results, despite world-wide endeavors $(73-80)$, as summarized in table 7 . This seems not only to be a methodological problem.(81), but the natural consequence of the non-specificity of lysozzyme elevation. 
Tab. 7. Lysozyme in serum (mg/l) in inflammatory bowel diseases $A=$ Agar plate method, $\mathbf{T}=$ Turbidimetric method

\begin{tabular}{|c|c|c|c|c|}
\hline Author(s) & Metho & d Controls & $\begin{array}{l}\text { Crohn's } \\
\text { Disease }\end{array}$ & $\begin{array}{l}\text { Ulcerative } \\
\text { Colitis }\end{array}$ \\
\hline $\begin{array}{l}\text { Falchuk et al. } \\
\text { (72) } \\
\text { Pruzanski \& }\end{array}$ & $\mathbf{A}$ & $8.8 \pm 0.3$ & $26.3 \pm 1.4$ & $9.3 \pm 0.6$ \\
\hline & $\mathbf{A}$ & $9.7 \pm 1.8$ & $8.3 \pm 2.3$ & $7.7 \pm 1.6$ \\
\hline & $\mathbf{T}$ & $17.5 \pm 3.4$ & $20.5 \pm 7.1$ & $17.6 \pm 5.6$ \\
\hline (75) & $\mathbf{T}$ & $7.0 \pm 2.0$ & $10.0 \pm 4.0$ & $7.0 \pm 2.0$ \\
\hline Farak (76) & $\begin{array}{l}\mathbf{A} \\
\mathbf{T}\end{array}$ & $\begin{array}{l}5.14 \\
4.81\end{array}$ & $\begin{array}{l}7.17 \\
5.00\end{array}$ & $\begin{array}{l}5.14 \\
4.90\end{array}$ \\
\hline $\begin{array}{l}\text { Röllinghoff et } \\
\text { al. (77) }\end{array}$ & $\mathbf{A}$ & $8.4 \pm 1.8$ & $8.1 \pm 3.0$ & $8.6 \pm 2.9$ \\
\hline $\begin{array}{l}\text { Klass \& Neale } \\
(78)\end{array}$ & $\begin{array}{l}A \\
T\end{array}$ & $\begin{array}{rr}27.4 & 17.5 \\
4.4 & \pm 2.0\end{array}$ & $\begin{array}{r}60.1 \pm 30.7 \\
9.2 \pm 2.7\end{array}$ & $\begin{array}{r}30.5 \pm 17.1 \\
7.3 \pm 5 .\end{array}$ \\
\hline $\begin{array}{l}\text { El-Khatib et al. } \\
\text { (79) }\end{array}$ & $\mathbf{A}$ & $6.0 \pm 1.5$ & $10.5 \pm 6.8$ & $9.6 \pm 4.1$ \\
\hline $\begin{array}{l}\text { Goesmann et } \\
\text { al. ( } 80 \text { ) un- } \\
\text { published) }\end{array}$ & $\mathbf{T}$ & $15.6 \pm 2.0$ & $20.8 \pm 5.2$ & $19.1 \pm 4.0$ \\
\hline
\end{tabular}

As the enzyme originates in the phagocytic cells of the inflamed tissue $(82,83)$, its activity in serum depends more on the severity of the process than on any other factor. However, in view of the broad overlap even betwee carefully defined and selected groups, lysozyme is helpful neither in differential diagnosis nor in follow-up.

The liver receives first hand most material which is absorbed and metabolized by the gut. It serves as a filter which protects the rest of the system. Thus, liver involvement must be expected to occur with any appreciable intestinal cell damage, despite the fact that much of the debris is released into the lumen. The reports on this subject, however, are contradictory. Excluding acute viral hepatitis, the incidence of liver involvement in ulcerative colitis and regional enterocolitis is given between $1.3 \%$ (84) and $4.8 \%(85)$ up to more than $70 \%(87,88,89)$ and $89 \%(86)$. Eade and his group have put forward the hypo- thesis of portal bacteremia as chief cause of secondary liver damage. However, they could not establish a good correlation (90).

Thus, clinical enzymology has not achieved a great deal to date in inflammatory bowel disease, including even the interesting findings of atypical alkaline phosphatases in serum $(91,92)$ or acid hydrolases in monocytes (93) reported by British investigators. Our own promising results with respect to the correlation between cholinesterase activity and severity of the illness will be published elsewhere.

\section{Tumors of the Large Bowel}

Colorectal cancers take first or second place among malignancies in many temperate countries. At present $50 \%$ of the patients are cured surgically. For the remaining half an earlier diagnosis must be effected.

Enzymatic diagnoses of tumors rely basically on marked differences in enzyme patterns between normal and malignant tissue, which can be reflected in serum. Baer and his associates have evaluated a large pattern of enzymes in colon mucosa and carcinoma (94). Their findings have been confirmed and extended by Dale (95) and Shonk et al (96). Table 8 shows the features of colon cancer as compared to normal mucosa for some selected enzymes: very low activity of enzymes with special functions, low values of enzymes which are connected with the citric acid cycle, unchanged bidirectional enzymes of carbohydrate metabolism and higher than normal glycolytic and hexose monophosphate pathway enzymes are characteristic. The enzyme pattern behaves similarly as has been shown by Weber for hepatomas (97) and by ourselves to a lesser degree for inflammatory liver diseases $(94,98)$. The alterations are not marked enough to yield significant changes in serum.

In colon cancer tissue, changes of the lactate dehydrogenase isoenzyme pattern towards the muscle type or

Tab. 8. Enzyme activities (U/g protein) in human colon mucosa and colon carcinoma (from Baer et al. (94)).

\begin{tabular}{|c|c|c|c|}
\hline & Normal mucosa & Adenocarcinoma & $\begin{array}{l}\text { Carcinoma/ } \\
\text { normal }\end{array}$ \\
\hline $\begin{array}{l}\text { Alanine aminotransferase }(2.6 .1 .2) \\
\text { Alcohol dehydrogenase }(1.1 .1 .1)\end{array}$ & $\begin{array}{l}29 \\
33\end{array}$ & $\begin{array}{l}1 \\
5\end{array}$ & $\begin{array}{l}0.03 \\
0.15\end{array}$ \\
\hline $\begin{array}{l}\text { Glycerol-3-phosphate dehydrogenase }\left(\mathrm{NAD}^{+}\right)(1.1 .1 .8) \\
\text { Aspartate aminotransferase }(2.6 .1 .1) \\
\text { Glutamate dehydrogenase }\left(\mathrm{NAD}(\mathrm{P})^{+}\right)(1.4 .1 .3) \\
\text { Isocitrate dehydrogenase }\left(\mathrm{NADP}^{+}\right)(1.1 .1 .42) \\
\text { Malate dehydrogenase }(1.1 .1 .37)\end{array}$ & $\begin{array}{r}31 \\
305 \\
164 \\
367 \\
2671\end{array}$ & $\begin{array}{c}10 \\
109 \\
61 \\
212 \\
1811\end{array}$ & $\begin{array}{l}0.32 \\
0.36 \\
0.37 \\
0.58 \\
0.68\end{array}$ \\
\hline $\begin{array}{l}\text { Phosphoglycerate kinase (2.7.2.3) } \\
\text { Enolāse (4.2.1.1) }\end{array}$ & $\begin{array}{r}1103 \\
215\end{array}$ & $\begin{array}{r}1119 \\
220\end{array}$ & $\begin{array}{l}1.01 \\
1.02\end{array}$ \\
\hline $\begin{array}{l}\text { Pyruvate kinase }(2.7 .1 .40) \\
\text { Glucose-6-phosphate dehydrogenase }(1.1 .1 .44) \\
\text { Lactate dehydrogenase }(1.1 .1 .27) \\
\text { Fructose-bisphósphate aldolase }(4.1 .2 .13)\end{array}$ & $\begin{array}{r}501 \\
20 \\
1299 \\
64\end{array}$ & $\begin{array}{r}745 \\
32 \\
2615 \\
129\end{array}$ & $\begin{array}{l}1.49 \\
1.60 \\
2.01 \\
2.02\end{array}$ \\
\hline
\end{tabular}


the mid-fractions have been found $(94,99)$. This has also been observed in normal mucosa near the tumor (101) and in precancerous lesions of ulcerative colitis (100). In serum, however, there is no reliable reflection of these changes.

Another approach to a timely diagnosis is based on the deletion of some normal mucosal antigens and the appearance of new cancer-associated ones which have been observed in various human tumors and in serum. The latter are thought to be incomplete antigens, and the underlying enzyme deficiencies have been searched for. The results of these endeavors are rather confusing:

Some presumably membrane-bound glycosyl transferases have been reported to be reduced, particularly in the presence of exogenous acceptors like CEA (table 9: 102,103). Others have been found increased and acceptorsensitive in tumor tissue and elevated in the serum of patients with colon cancer $(104,105,106)$. Distinct isoenzymes of galactosyl transferase $(104,106)$ and of $\beta$-hexosaminidase (107) have been described recently.

Collagenase $(68,108)$ and acid hydrolases $(109)$ have been shown increased in tumor tissue (table 10). On. the other hand, a decrease of acid phosphatase and of $\alpha$-naphthyl-acetyl-esterase was found (110).

At present, enzyme determinations in serum seem to be of little use for the timely diagnosis of colorectal malignancies. This is also true with the Regan variant of alkaline phosphatase $(111,112)$ and for the excretion of arylsulfatase B in urine $(113,114)$.

Tab. 9. Glycosyltransferase activity in homogenates of normal and malignant human colon epithelium (from LaMont \& Isselbacher (103)) Endogenous activity refers to incorporation into gly coprotein acceptors present in the homogenate and has been subtracted from the activity in exogenous acceptors.

\begin{tabular}{|c|c|c|}
\hline \multirow{2}{*}{ Enzyme } & \multicolumn{2}{|c|}{$\begin{array}{l}\text { Monosaccharide transferred } \\
\text { (pmol/30 min }{ }^{-} \mathrm{mg} \text { protein) }\end{array}$} \\
\hline & Normal & Carcinoma \\
\hline \multicolumn{3}{|l|}{ Galactosyltransferase: } \\
\hline $\begin{array}{l}\text { Endogenous } \\
\text { Sialic acid, galactose- }\end{array}$ & 67 & 78 \\
\hline free fetuin & 1068 & 526 \\
\hline $\begin{array}{l}\text { Fucosyltransferase: } \\
\text { Endogenous }\end{array}$ & & \\
\hline $\begin{array}{l}\text { Endogenous } \\
\text { Sialic acid-free } \alpha_{1} \text {-acid }\end{array}$ & 118 & 126 \\
\hline glycoprotein & 713 & $132 \cdots$ \\
\hline Sialyltransferase: & & \\
\hline Endogenous & 3 & 1 \\
\hline $\begin{array}{l}\text { Sialic acid-free fetuin } \\
N \text {-acetylglucosaminyl- } \\
\text { transferase: }\end{array}$ & 29 & 27 \\
\hline $\begin{array}{l}\text { Endogenous } \\
\text { Mannosyltransferase: }\end{array}$ & 30 & 9 \\
\hline Endogenous & $<1$ & $<1$ \\
\hline
\end{tabular}

Tab. 10. Glycosidase, acid phosphatase, and protease activity in normal mucosa and colorectal carcinomas (from Bosmann \& Hall (109)). Values in italics: $\mathrm{P}<0.05$.

\begin{tabular}{|c|c|c|}
\hline & $\begin{array}{l}\text { Normal } \\
\text { (nmol/h } \cdot \mathrm{mg} \\
\text { protein) } \\
\left(\overline{\mathbf{x}} \pm s_{\overline{\mathbf{x}}}\right) \\
(\mathrm{n})\end{array}$ & $\begin{array}{l}\text { Tumor } \\
\text { (nmol/h } \cdot \mathrm{mg} \\
\text { protein) } \\
(\overline{\mathbf{x}} \pm \mathrm{s} \overline{\mathbf{x}}) \\
(\mathrm{n})\end{array}$ \\
\hline \multirow{7}{*}{$\begin{array}{l}\beta \text {-Galactosidase (3.2.1.23) } \\
\alpha \text {-Fucosidase }(3.2 .1 .-) \\
\beta-\mathrm{N}-\text { Acetylgälacto saminidase } \\
(3.2 .1 .-) \\
\beta-\mathrm{N}-\text { Acetylglucosaminidase } \\
(3.2 .1 .30) \\
\alpha-\text { Mannosidase }(3.2 .1 .24) \\
\text { Acid phosphatase }(3.2 .3 .2) \\
\text { Neuraminidase }(3.2 .1 .18)\end{array}$} & $108 \pm 35(6)$ & $236 \pm 41(7)$ \\
\hline & $1 \pm 1(6)$ & $1 \pm 1(7)$ \\
\hline & $223 \pm 64(6)$ & $317 \pm 42(7)$ \\
\hline & $413 \pm 98(6)$ & $355 \div 41(7)$ \\
\hline & $42 \pm 13(6)$ & $116 \pm 23(7)$ \\
\hline & $343 \pm 54(5)$ & $340 \pm 37(6)$ \\
\hline & $103 \pm 41(6)$ & $303 \pm 41(7)$ \\
\hline $\begin{array}{l}\text { Protease, pH } 3.4 \text { (3.4.4.9) } \\
\text { Protease, pH } 7.4 \text { (3.4.4.4) }\end{array}$ & $\begin{array}{l}489 \pm 68(5) \\
164 \pm 65(6)\end{array}$ & $\begin{array}{l}1399 \pm 418(7) \\
.211 \pm 107(7)\end{array}$ \\
\hline
\end{tabular}

There is still a controversy about the value of enzyme determinations in serum for monitoring the course of colorectal cancer and for the early detection of liver metastases. The conclusion to which the individual investigators come, depends largely on the number of enzymes measured, and still more on the care bestowed upon the interpretation of the results. Thus, those who measure only one enzyme or count only "positives" and "negatives", feel that they cannot rely on their findings, especially because of the high rate of "false-positives" $(115-121)$. This is demonstrated in table 11 and has been amply discussed by Read (121). There are, how-

Tab. 11. Diagnostic value of the determination of alkaline phosphatase and lactate dehydrogenase in colorectal cancer (from Read et al. (121)).

\begin{tabular}{|c|c|c|c|c|c|}
\hline Series & $\begin{array}{l}\text { Number } \\
\text { of Cases }\end{array}$ & $\begin{array}{l}\text { Number } \\
\text { Elevated }\end{array}$ & $\begin{array}{l}\text { Correct } \\
\text { values } \\
(\%)\end{array}$ & $\begin{array}{l}\text { False- } \\
\text { negative } \\
\text { values } \\
(\%)\end{array}$ & $\begin{array}{l}\text { False- } \\
\text { positive } \\
\text { values } \\
(\%)\end{array}$ \\
\hline
\end{tabular}

Alkaline Phosphatase

\begin{tabular}{|c|c|c|c|c|}
\hline $\begin{array}{l}\text { Gennaro \& } \\
\text { Bacon }\end{array}$ & 146 & - & - & 15 \\
\hline $\begin{array}{l}\text { Almersjo } \\
\text { et al. }\end{array}$ & 90 & 67 & 78 & 52 \\
\hline $\begin{array}{l}\text { Ranson } \\
\text { et al. }\end{array}$ & 117 & 6 & 85 & 15 \\
\hline $\begin{array}{l}\text { Fee et al. } \\
\text { Ariel \& } \\
\text { Shahon }\end{array}$ & $\begin{array}{l}70 \\
22\end{array}$ & $\begin{array}{r}40 \\
2\end{array}$ & $\begin{array}{l}63 \\
64\end{array}$ & $\begin{array}{l}13 \\
36\end{array}$ \\
\hline $\begin{array}{l}\text { Gollin et al. } \\
\text { Guitierrez }\end{array}$ & 125 & 82 & 76 & 56 \\
\hline $\begin{array}{l}\text { et al. } \\
\text { Present } \\
\text { series* }\end{array}$ & $\begin{array}{l}106 \\
123\end{array}$ & $\begin{array}{l}14 \\
34\end{array}$ & $\begin{array}{l}93 \\
78\end{array}$ & $\begin{array}{l}3 \\
9\end{array}$ \\
\hline
\end{tabular}

\section{Lactate Dehydrogenase}

$\begin{array}{lrrrrr}\text { Ranson et al. } 113 & 23 & 91 & 4 & 26 \\ \text { Gollin et al. } & 67 & 37 & 60 & 83 & 5 \\ \text { Present } & 118 & 30 & 78 & 13 . & 50\end{array}$
series* * Present series = Read et al. $(121)$; for the other references
given see l.c. $(121)$. 
Tab. 12. Enzyme pattern in serum characteristic for liver metastases of gastro-intestinal carcinomas (from 1.c. (127130)).

\begin{tabular}{|c|c|}
\hline $\begin{array}{l}\text { Aminotransferases: } \\
\text { (aspartate: GOT; alanine: GPT) } \\
\text { Glutamic dehydrogenase (GLDH) } \\
\text { Alkaline phosphatase: } \\
\gamma \text {-Glutamyl transferase ( } \gamma \text {-GT): } \\
\text { Lactate dehydrogenase (LDH): } \\
\text { Cholinesterase: }\end{array}$ & $\begin{array}{l}\text { slight - moderate increase: } \\
\text { GOT/GPT > } 1.0 \\
\text { :slight - marked increase: } \\
\text { GPT/GLDH < } 10 \\
\text { slight - marked increase: } \\
\text { moderate - marked increase: } \\
\gamma \text {-GT/GOT > } 1.0 \\
\text { slight - moderate increase: } \\
\text { HBDH*/LDH = normal } \\
\text { slight - marked reduction: } \\
20-60 \%\end{array}$ \\
\hline
\end{tabular}

* $\mathrm{HBDH}=$ hydroxybutyrate dehydrogenase

ever, also positive voters, who consider enzyme determinations suitable as screening methods (122-126). In our experience the pattern outlined in table 12 has stood the test in routine examinations for more than a decade in disclosing and discriminating hepatic metastases to the extent of more than $80 \%(127-130)$.
At the end of this chapter an interesting preliminary study of Sykes et al. may be mentioned: From 18 cases of human colorectal carcinoma they found in 10 cases high, and in 8 cases low superoxide dismutase activity (131). As it has been shown that tissues with a high activity of this enzyme are resistent to ionizing irradiation and vice versa (132), possible radiation sensitivity of tumors can be predicted and moreover, by inhibition of high superoxide dismutase activity, might be enhanced.

\section{Side Effects of Therapy}

It is self-evident that cytostatic drugs affect a tissue which proliferates as fast as intestinal epithelium. The disaccharidases are the best investigated enzymes in this respect. Their activity decreases faster than would be expected by a pure antimitotic effect upon the crypt cells; therefore, a direct toxic action on the brush border membranes with release of the respective enzymes must also be taken into consideration (table $13 ; 133-143$ ).

Tab. 13. Effects of cytostatic drugs on brush border enzymes of rat intestine (from Ecknauer \& Rommel (133)) $\downarrow=$ decreased; $\uparrow=$ increased; = unchanged.

\begin{tabular}{|c|c|c|c|c|}
\hline Cytostatic Drug & Dose (mg/kg) & $\begin{array}{l}\text { Enzyme } \\
\text { alteration }\end{array}$ & Time (h) & Author(s)* Year \\
\hline Aminopterine & $\begin{array}{l}1 \times 1.2 \\
7 \times 0.2\end{array}$ & $\begin{array}{l}\text { SA/LA } \\
\text { MA }\end{array}$ & $\begin{array}{l}t \\
t\end{array}$ & $\begin{array}{l}\text { Wolff, } 1967 \\
\text { Schiraldi et al. } 1961\end{array}$ \\
\hline Colchicine & $\begin{array}{l}1 \times 1.0 \\
3 \times 1.0 \\
1 \times 1.0\end{array}$ & $\begin{array}{l}\text { SA } \\
\text { MA } \\
\text { ALP }\end{array}$ & $\begin{array}{l}\downarrow \\
\downarrow \uparrow \\
\downarrow\end{array}$ & $\begin{array}{l}\text { Herbst et al. } 1970 \\
\text { Herbst et al. } 1970 \\
\text { Fredericson et al. } 1956\end{array}$ \\
\hline Cyclophosphamide & $1 \times 100$ & $\begin{array}{l}\text { MA/SA/LA } \\
\text { ALP } / \boldsymbol{\gamma}-\mathrm{GT}\end{array}$ & $\begin{array}{rr}= & 24+48 \\
= & 6+12\end{array}$ & Ecknauer et al. 1976 \\
\hline 5-Fluorouracil & $\begin{array}{l}1 \times 40 \\
1 \times 250 \\
1 \times 375\end{array}$ & $\begin{array}{l}\text { MA/TA/LA/CA } \\
\text { MA/SA/LA/CA } \\
\text { ALP/SA }\end{array}$ & $\begin{array}{l}\downarrow \\
\downarrow \downarrow \\
\uparrow \uparrow 24 \\
\downarrow \downarrow 72\end{array}$ & $\begin{array}{l}\text { Mielcke, } 1975 \\
\text { Hartwich et al. } 1974 \\
\text { Bounous } 1971\end{array}$ \\
\hline Vincristin & $1 \times 0.1$ & SA/MA & $\downarrow$ & Hartwich et al. 1976 \\
\hline
\end{tabular}

MA = Maltase; SA = Saccharase $;$ LA = Lactase $\mathrm{CA}=$ Cellobiase; TA = Trehalase $; \mathrm{ALP}=$ Alkaline Phosphatase; $\gamma$-GT $=\gamma$-Glutamyltransferase.

*for complete references see l.c. (133)

Tab. 14. Effect of various drugs on the activity of alkaline phosphatase* in human feces (from (Frolkis et al. (145)).

\begin{tabular}{lcccc}
\hline Drug** & $\mathrm{n}$ & Bëfore treatment & P & After treatment \\
\hline Chloramphenicol & 14 & $273 \pm 36.6$ & $<0.001$ & $936 \pm 90.5$ \\
Oleandomycin & 10 & $422 \pm 29.7$ & $<0.001$ & $1048 \pm 78.3$ \\
Tetrącycline & 13 & $329 \pm 43.0$ & $<0.001$ & $1021 \pm 71.0$ \\
Furazolidone & 10 & $286 \pm 58.0$ & $<0.01$ & $598 \pm 49.0$ \\
Halquinol/Phanquone & 11 & $583 \pm 108$ & n.s. & $561 \pm 83.0$ \\
Sulfaguanidine & 7 & $460 \pm 157$ & $<0.02$ & $1160 \pm 151$ \\
Salazosulfapyridine & 10 & $550 \pm 76.0$ & n.s. & $472 \pm 64.0$ \\
Furosemide & 5 & $323 \pm 147$ & n.s. & $391 \pm 188$ \\
Tolbutamide & 7 & $83 \pm 13.0$ & n.s. & $102 \pm 10.0$ \\
\hline
\end{tabular}

* Arbitrary Units/g feces (Normal range $45-420 \mathrm{AU} / \mathrm{g}$ )

** Drugs given in therapeutical doses for 7-8 days.

J. Clin. Chem. Clin. Biochem. / Vol. 17, 1979 / No. 11 
Another group of drugs which is well known to affect structure and function of intestinal mucosa is that of antibiotics and other antibacterial substances. Several antibiotics - especially neomycin - lead to severe villous atrophy as a consequence of their inhibition of protein synthesis and their impairment of selective membrane permeability (144). Whether the elevated activity of alkaline phosphatase and of other enzymes in the feces after the administration of some antibiotics is due to a higher release from damaged cells or to a diminished degradation by the reduced microflora of the gut (table $14 ; 145)$, is still under discussion.

Another aspect is that bacterial overgrowth has been blamed for many manifestations in the blind loop
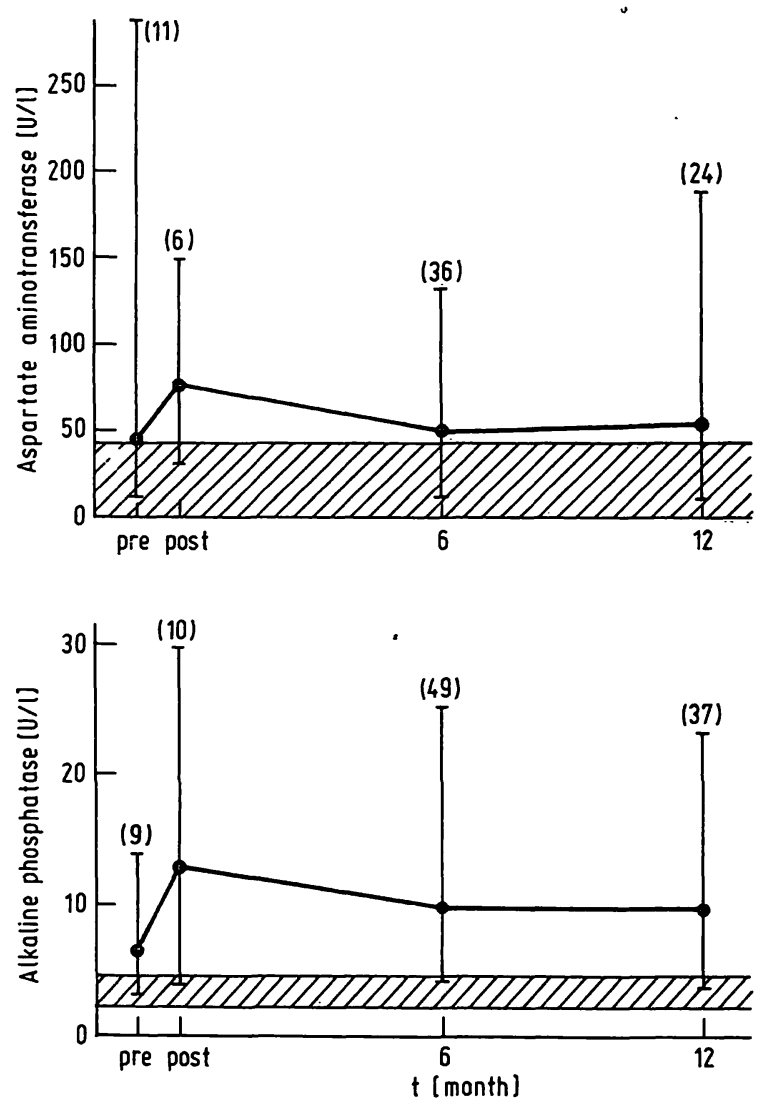

Fig. 9. Enzyme activity in serum before and after jejuno-ileal bypass for morbid obesity. The bars give means \pm range. From Spin \& Weismann (146). syndromes (154), and that its role together with the stasis of the secretions in the long excluded bowel segment has been emphasized by some of the authors $(147,148)$ who report liver damage after jejuno-ileal bypass for massive obesity (146-150). Figure 9 shows that liver parenchymal cell damage is common thereafter, but of variable degree. As a rule, it is not the fatty liver of the malnourished that is found, but a toxic injury resembling alcoholic hepatitis.

The intestine itself seems to compensate within weeks to months to its altered function, as it is shown in figure 10 by the example of alkaline phosphatase (153). While in the excluded, non-functioning long segment most enzyme activities decrease, in both short functioning segments there are increases up to 4 times which are more marked in the ileum than in the jejunum. This is, in an extreme artificial situation, further proof for the enormous capacity of adaptation of the gut enzymes, which makes the differentiation between cause and effect in bowel enzymology so difficult.

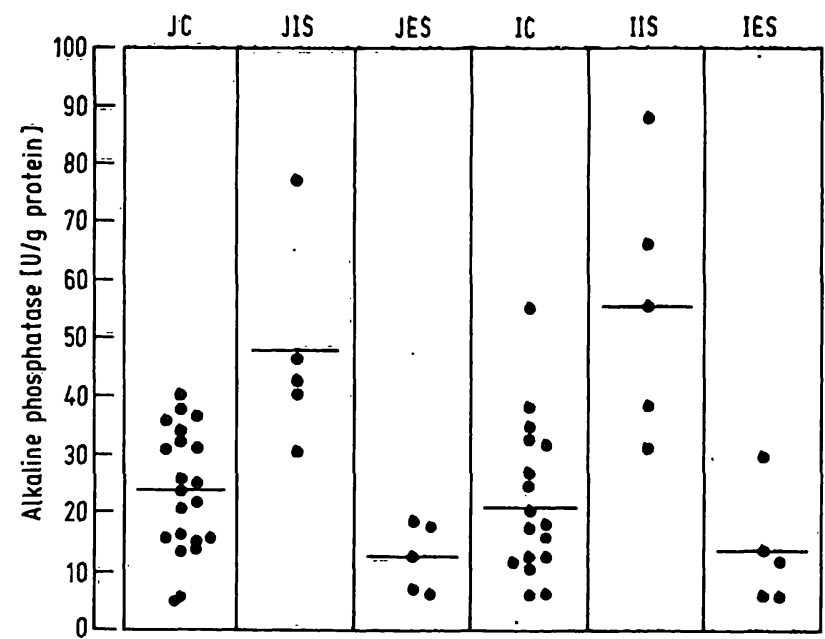

Fig. 10. Specific activities of alkaline phosphatase (U/g protein) Mean enzyme activity of each segment is given as a bar. Preoperative specimens: jejunal control (JC) and ileal control (IC). Postoperative specimens: jejunal included segment (JIS), jejunal excluded segment (JES), ileal included segment (IIS), ileal excluded segment (IES). From Stein \& Wise (153).

\section{References}

1. Gannon, B. J., Burnstock, G., Noblett, H. R. \& Campbell, P. G. (1969), Lancet $I, 894-895$.

2. Meier-Ruge, W., Lutterbeck, P. M., Herzog, B., Morger, R., Moser, R. \& Schärli, A. (1972), J. Pediatr. Surg. 7, 11-17.

3. Lake, B. D., Prem, P., Nixon, H. H. \& Claireaux, A. E. (1978), Arch. Pathol. Lab. Med. 102, 244-247.

4. Toorman, J., Bots, G. T. A. M. \& Vio, P. M. A. (1977), Virchows Arch. Pathol. Anat. Histol. 376, 159-164.

5. Boston, V.. E., Dale, G. \& Riley, K. W. A. (1975), Lancet II, 951-953.
6. Dale, G., Bonham, J. R., Riley, K. W. A. \& Waggat, J. (1977), Clin. Chim. Acta 77, 407-413.

7. Boston, V. E., Cywes, S. \& Davies, M. R. Q. (1978), J. Pediatr. Surg. $13,407-410$.

8. Jussila, J., Launiala, K. \& Gorbalow, O. (1969), Acta Med. Scand 186, 217-222.

9. Weser, E., Rubin, W., Ross, L. \& Sleisenger, M. H. (1965), New Engl. J. Med. 273, 1070-1075.

10. Andersson, D. E. H. \& Nygren, A. (1978), Acta Med. Scand. 203, 87-92. 
11. Ament, M. E., Perera, D. R. \& Esther, L. J. (1973), J. Pediatr $83,721-727$.

12. Gudmand-Höyer, E. \& Krasilnikoff, P. A. (1977), Scand. J. Gastroenterol. 12, 103-107.

13. Dubs, R., Steinmann, B. \& Gitzelmann, R. (1973), Helvet. Paediatr. Acta 28, 187-198.

14. Laplane, R., Polonovski, C., Etienne, M., Debray, P., Lods, J. C. \& Pissarro, B. (1962), Arch. Franc. Pédiatr. 19, 895-899.

15. Hughes, W. S. \& Senior, J. R. (1975), Gastroenterology 68 , $142-145$.

16. Rosensweig. N. S. (1975), Am. J. Clin. Nutr. 28, 648-655.

17. Green, H. L., Stifel, F. B. \& Herman, R. H. (1972), Biochem. Med. 6, 409-418.

18. Rosensweig, N. S., Herman, R. H., Stifel, F. B., Hagler, L., Greene, H. L. jr. \& Herman, Y. F. (1972), Gastroenterology $62,802$.

19. Flatz, G. \& Rotthauwe, H. W. (1977), Progr. Genetics 2 , 205-259.

20. Simoons, F. J. (1970), Am. J. Dig. Dis. 15, 695-710.

21. Johnson, J. D., Kretchmer, N. \& Simoons, F. J. (1974), Adv. Pediatr. 21, 197-237.

22. Cavalli-Sforza, L. L. (1973), Am. J. Hum. Genet. 25, 82-104.

23. Flatz, G. \& Rot thauwe, H. W. (1973), Lancet II, 76-77.

24. Fournier, P., Dupuis, Y. \& Fournier, A. (1971), Isr. J. Med. Sci. 7, 389-391.

25. Leichter, J. \& Tolensky, F. (1975), Am. J. Clin. Nutr. 28, $238-241$.

26. Reche, O. \& Lehmann, W. (1959), Die Genetik der Rassenbildung beim Menschen. In: Die Evolution der Organismen (Heberer, G. ed.). Fischer, Stuttgart pp. 1143-1191.

27. Loomis, W. F. (1967), Science 157, 501-506.

28. Condon, J. R., Nassim, J. R., Millard, F. J. C., Hilbe, A \& Stain thorpe, E. M. (1968), Lancet $1,1027-1029$.

29. Kocián, J., Skála, I. \& Bakos, K. (1973), Digestion 9, 317-3224.

30. Perlow, W., Baraona, E. \& Lieber, C. S. (1977), Gastroenterology 72, 680-684.

31. Berg, N. O., Dahlquist, A., Lindberg, T. \& Nordén, A. (1973), Scand. J, Gastroenterol. 8, 703-712.

32. Gjessing, E. C., Villanueva, D., Duque, E., Mayoral, L. G. \& Bolanos, O. (1977), Am. J. Clin. Nutr. 30, 1044-1053.

32a. Lojda, Z., Fric, P., Jodl, J. \& Chmelík, V. (1970), Curr. Top. Pathol. 52, 1-63.

33. Malis, F., Lojda, Z., Fric, P. \& Jodl, J. (1972), Digestion $S$, 40-48.

34. Grävinghoff, J. \& Hütter, H. J. (1977), Eur. J. Pedịatr. 127, 57-62.

35. Rossiter, M. A., Burgess, E. A. \& Libermann, M. M. (1974), Acta Paediatr. Scand. 63, 162.

36. Peters, T. J., Heath, J. R., Wansbrough-Jones, M. H. \& Doe, W. F. (1975), Clin. Sci. Mol. Med. 48, 259-267.

37. Peters, T. J., Jones, P. E. \& Wells, G. (1978), Clin. Sci. Mol. Med. 55, 285-292.

38. Malathi, P. \& Crane, R. K. (1969), Biochim. Biophys. Acta $173,245-256$.

39. Gossran, R. (1975), Acta Histochem. Cy tochem. 8, 153-163.

40. Phelan, J. J., Stevens, F. M., McNicholl, B., Fottrell, P. F. \& McCarthy, C. F. (1977), Clin. Sci. Mol. Med. 53, 35-43.

41. Douglas, A. P. (1976), Clin. Chim. Acta 73, 357-361.

42. Eggermont, E., Molla, A. M., Tytgat, G. \& Rutgeerts, L. (1971), Gastroenterol. Bel. 34, 655-662.

43. WWoodley, J. F. \& Keane, R. (1972), Gut 13, 900-902.

44. Niessen, K. H. Schmidt, K. \& Brügmann, G. (1973), Mschr. Kinderheilk. 121, 49-53.

45. Lebenthal, E., Antonowicz, I. \& Shwachman, H. (1975), Pediatirics 56, 585-592.

46. Lebenthal, E., Antonowicz, I. \& Shwachman, H. (1976), Gastroenterology 70, 508-512.

47. Morin, C. L., van Caillie, M., Roy, C. C. \& Lasalle, R, (1977), Pediatrics 60, 114-116.

48. Takano, K., Sużuki, T. \& Yasuda, K. (1971), Okajima Folia Anat. Japn. 48, 15-23.

49. Avery, G. B. Villavicenclo, O., Lilly, J. R. \& Randolph, J. G. (1968), Pediatrics 41, 712-722.

50. Shwachman, H., Lloyd-Still, J. D., Khaw, K. T. \& Antonowicz, I. (1973), Am. J. Dis. Child. 125, 365-368.

51. Hadorn, B., Steiner, N., Sumida, C. \& Peters, T. J. (1971), Lancet $I, 165-166$.
52. Cohen, M. I., McNamara, H., Blumenfeld, D. \& Arias, I. M. (1970), The relationship between $\gamma$-glutamyl-transpeptidase and the syndrome of celiac sprue. In: Coeliac Disease (Booth, C. C. \& Dowling, R. H. eds.) Churchill Livingstone, Edinburgh p. 91 .

53. Falchuk, Z. M., Gebhard, R. L. \& Strober, W. (1974), The pathogenesis of gluten sensitive enteropathy (coeliac sprue): organ culture studies. In: Coeliac Disease (Hekkens, W. T. J. M. \& Pena, A. S. eds.) Stenfert Kroease, Leyden pp. 107-117.

54. Fairman, M. J., Scott, B. B., Toothill, C \& Losowsky, M. S. (1977), Gut 18, 484-487.

55. Cerda, J. J., Preiser, H. \& Crane, R. K. (1972), Gastroenterology 62,841 .

56. Arvantakis, C. \& Olsen, W. A. (1974), Am. J. Dig. Dis. 19, 417-421.

57. Antonowicz, I., Lebenthal, E. \& Shwachman, H. (1978), Pediatrics 92, 214-219.

58. Gray, G. M. \& Santiago, N. A. (1966), Gastroenterology 51 , 489-498.

59. Gudmand-Höyer, E. \& Söcberg, B. (1974), Scand. J. Gastroenterol. 9, 405-409.

60. Barnes, G. L., Bishop, R. F. \& Townley, R. R. W. (1974), Acta Paediatr. Scand. 63, 423-426.

61. Lücking, T. (1976), Eur. J. Pediatr. 121, 263-277.

62. Cook, G. C. \& Lee, F. D. (1966), Lancet II, 1263-1267.

63. Gray, G. M., Walter, W. M. jr. \& Colver, E. H. (1967), Gastrqenterology 54, 552-558.

64, Gudmand-Höyer, E., Binder, V. \& Sötoft, J. (1975), Scand. J. Gastroenterol. 10, 209-212.

65. Allan, R., Steinberg, D. M., Dixon, K. \& Cooke, W. T. (1975), Gut $16,201-204$.

66. Dunne, W. T., Cooke, W. T. \& Allan, R. N. (1977), Gut 18, 290-294.

67. Shalev, E., Stojahn, B. \& Fahrländer, H. (1976), Dtsch. Med. Wochenschr. 101, 685-687.

68. Sturzacker, H. G. \& Hawley, P. R. (1975), Proc. Roy. Soc. Med. $68,33$.

69. Gọodman, M. J., Kent, P. W. \& Truelove, S. C. (1977), Gut 18 219-228.

70. Goodman, M. J., Kent, P. W. \& Truelove, S. C. (1977), Gut 18 229-231.

71. Farthing, M. J. G., Dick, A. P., Heslop, G. \& Levene, C. I. (1978), Gut 19, 743-747.

72. Falchuk, K. R., Perrotto, J. L. \& Isselbacher, K. J. (1975), N. Engl. J. Med. 292, 395-397.

73. Pruzanski, W. \& Marcon, N. (1975), N. Engl. J. Med. 192 , $611-612$.

74. Peeters, T. L. Vantrappen, G. \& Geboes, K. (1976), Gut 17, 300-305.

75. Nugent, F. W., Mallari, R., George, H. \& Ridley, N. (1976), Gaştroenterology 70, 1014-1016.

76. Farak, U. (1976), 31. Tg. d. Dtsch. Ges. Verdauungs- u. Stoffwechsel-Krankheiten.

77. Röllinghoff, W., Brandes, J. W., Ehms, H., Miller, B. Schmülling, R. M., Tischendorf, F. W. \& Malchow, H. (1977), Klin. Wochenschr. 55, 225-230.

78. Klass, H. J. \& Neale, G. (1978), Gut 19, 233-239.

79. El-Khatib, O. S., Lebwohl, O., Attia, A. A., Flood, C A. Stein, J. A., Sweetig, J. G., Whitlock, R. T., Osserman, E. F. \& Holt, P. R. (1978), Am. J. Dig. Dis. 23, 297-301.

80. Goesmann, C., Müller, R., Schmidt, E. \& Schmidt, F. W., unpublished.

81. Johansson, B. G. \& Ursing, B. (1976), N. Engl. J. Med. 294, 337.

82. Klockars, M., Reitamo, S., Reitamo, J. J. \& Möller, C. (1977), Gut 18, 377-381.

83. Pott, G., Schmidt, A., Buddecke, E. \& Gerlach, U. (1977), Klin. Wochenschr. 55, 557-558.

84. Greenstein, A. J., Janowitz, H. D. \& Sachar, D. B. (1976), Medicine 55, 401-412.

85. Edwards, F. C. \& Truelove, S. C. (1964), Gut 5, 1-22.

86. Dordal, E., Glagov, S. \& Kirsner, J. B. (1967), Gastroenterology 52, 239-253.

87. Eade, M. N. (1970), Ann. Intern. Med. 72, 475-487.

88. Eade, M. N., Cooke, W. T. \& Brooke, B. N. (1971), Ann. Intern. Med. 74, 518-528. 
89. Eade, M. N., Cooke, W. T. \& Williams, J. A. (1971), Scand. J. Gastroenterol. 6, 199-204.

90. Eade, M. N. \& Brooke, B. N. (1969), Lancet I, 1008-1009.

91. Qirby, A. A. \& Moss, D. W. (1975), Clin. Chim. Acta 60, $1-6$.

92. Rosalki, S. B. \& Hurst, N. P. (1976), Clin. Chim. Acta 73, 149-155.

93. Ganguly, N. K., Kingham, J. G. C., Lloyd, R. S., Lloyd, B. Price, C P., Triger, D. R. \& Wright, R. (1978), Lancet $I$, 1073-1075.

94. Baer, U., Schmidt, E. \& Schmidt, F. W. (1963), Klin. Wochenschr. 41, 977-988.

95. Shonk, C. E., Arison, R. N., Koven, B. J., Majima, H. \& Boxer, G. E. (1965), Cancer Res. 25, 206-213.

96. Dale, R. A. (1965), Clin. Chim. Acta 11, 547-556.

97. Weber, G. (1962), Adv. Cancer Res. 6, 403-487.

98. Schmidt, E. \& Schmidt, F. W. (1963), Klin. Wochenschr. 4I, $649-653$.

99. Langvad, E. (1968), Int. J. Cancer 3, 17-29.

100. Lewis, B., Morson, B. C., February, A. W., Jones, J. H. \& Misiewicz, J. J. (1970), Gut 12, 16-19.

101. Taylor, R.. Cumberland, V. H. \& Piper, D. W. '(1977), Gut 18 , $45-47$.

102. Kim, Y. S., Perdomo, J. \& Isaacs, R. (1974), J. Clin. Invest. 53, 134. Fredericsson, B. \& Wirse, C. (1956), Exptl. Cell Res. 10, 39 a.

103. LaMont, T. J. \& Isselbacher, K. J. (1975), J. Nat. Cancer Inst. 54, 53-56.

104. Podolsky, D. K., Weiser, M. M. \& Isselbacher, K. J. (1977), J. Biol. Chem. 252, 1807-1813.

105. Ganzinger, U., Borner, F., Unger, F. M., Moser, K. \& Jentzsch, K. (1977), Klin. Wochenschr. 55, 553-555.

106. Podolsky, D. K., Weiser, M. M., Isselbacher, K. J. \& Cohen, A. M. (1978), N. Engl. J. Med. 299, 307-305.

107. Bratain, M. G., Kimball, P. M. \& Pretlow, T. G. (1977), Cancer Res. 37, 731-735

108. Dresden, M. H., Heilmann, S. A. \& Schmidt, J. D. (1972), Cancer Res. 32, 933-996.

109. Bosmann, H. B. \& Hall, T. C. (1974), Proc. Nat. Acad. Sci. USA 71, 1833-1837.

110. Koudstal, J., Makkink, B. \& Overdiep, S. H. (1975), Europ. J. Cancer 11, 105-109.

111. Klein, U. E. (1968), Lancet $I I, 1396$.

112. Crofton, P. M. \& Smith, A. F. (1978), Clin. Chim. Acta 86, $81-88$

113. Morgan, L. R. jr., Samuels, M. S., Thomas, W., Krementz, E. T. \& Meeker, W. (1975), Cancer 36, 2337-2345.

114. Schwartz, M. K. (1977), Cancer 40, 2620-2624.

115. Baden, H., Andersen, B., Augustenborg, G. \& Hanel, H. K. (1971), Surgery 133, 769-773.

116. Irvin, T. T., Edwards, J. P. \& Goligher, J. C. (1973), Brit. J. Surg. 60, 347-349.

117. Plomteux, G. \& Toulet, J. (1974), Sem. Hôp. Paris 50, $1931-1933$.

118. Korsten, C. B., Persijn, J. P. \& van der Slik, W. (1974), Z. Klin. Chem. Klin. Biochem. 12, 116-120.

119. Angehrn, F. G., Schmid, P., Pescia, R., Horica, C. A., Koelz, H. R., Herz, R., Cueni, B., Schmid, M., Akovbiantz, A. Heinzel, F., Landolt, M., Haemmerli, U. P. \& Blum, A. L. (1976), Dtsch. Med. Wochenschr. 101, 1047-1055.

120. Shani, A., O'Connell, M. J., Moertel, C. G., Schutt, A. J., Silvers, A. \& Go, V. L. (1978), Ann. Int. Med. 88, 627-630.

121. Read, D. R., Hambridge, E., Abcarian, H. \& Levine, H. (1977), Dis. Colon Rectum 20,101-106.
122. Dallüge, K. H., Eichhorn, H. J., Ziegenbein, R., Hüttner, J. \& Richter, E. (1971), Dtsch. Ges.wesen 26, 2153-2158.

123. Cederqvist, C. \& Nielsen, J. (1972), Acta Chir. Scand. 138 , 604-608.

124. Steele, L., Cooper, E. H., Mackay, A. M., Losowsky, M. S. \& Goligher, J. C. (1974), Br. J. Cancer 30, 319-324.

125. Cooper, E. H., Turner, R., Steele, L., Neville, A. M. \& Mackay, A. M. (1975), Br. J. Cancer 31,111-117.

126. Almersjö, O., Bengmark, S. \& Hafström, L. (1976), Cancer $37,1454-1457$.

127. Kärcher, K. H., zum Winkel, K. \& Goergi, M. (1974), Klin. Wochenschr. 42, 1241-1246.

128. Jenny, S. (1967), Acta Hepato-Splen. 14, 317-325.

129. Hammer, B., Weber, H. \& Wegmann, T. (1967), Z. Gastroenterologie $5,149-157$.

130. Schmidt, E. \& Schmidt, F. W. (1969), German Med. Monthly 14, 90-92.

131. Sykes, J. A., McCormack, F. X. \& O'Brien, T. J. (1978), Cancer Res. 38, 2759-2762.

132. Hartz, J. W., Funokoshi, S. \& Deutsch, H. F. (1973), Clin. Chim. Acta 46, 125-132.

133. Ecknauer, R. \& Rommel, K. (1978), Klin. Wochenschr. 56, 579-592.

$$
\text { 749-751. }
$$

135. Schiraldi, O. \& Marano. R. (1961), Rass. Fisiopatol. Clin. Ter. 33, 920-934.

136. Wolff, G. (1967), Ber. Ges. Inn. Med. 5, 159-160.

137. Herbst, J. J., Hurwitz, R., Sunshine, P. \& Kretchmer, H. (1970), J. Clin. Invest. 49, 530-536.

138. Bounous, G., Hugon, J. \& Gentille, J. M. (1971), Canad. J. Surg. 14, 298-311.

139. Hartwich, G., Domschke, W., Matzkies, F., Pesch, H. H. \& Prestele, H. (1974), Klin. Wo chenschr. 52, 930-938.

140. Mielke, F. (1975), Gastroenterol. 13, 356-361.

141. Ecknauer, R. (1976), Acta Hepato-Gastroenterol. 23, $365-371$

142. Ecknauer, R. \& Löhrs, U. (1976), Digestion 14, 269-280.

143. Hartwich, G., Leicher, H., Müller, H., Domschke, W. \& Matzkies, F. (1976), Arzneimittelforsch. 26, 58-62.

144. De Jonge, H. R. (1973), Biochem. Pharmacol. 22, 2659 2677.

145. Frolkis, A. W., Fedotowa, O., Gilenko, T. \& Rosenbaum, J. (1975), Dtsch. Z. Verdau. Stoffwechselkr. 35, 219-227.

146. Spin, F. P. \& Weismann, R. E. (1975), Am. J. Surg. 130, 88-91.

147. Brown, R. G., O'Leary, J. P. \& Woodward, E. R. (1974), Am. J. Surg. 127, 53-58.

148. Quaade, F., Juhl, E., Feldt-Rasmussen, K. \& Baden, H. (1971), Scand. J. Gastroenterol. 6, 537-541.

149. Lundström, B. \& Gillquist, J. (1975), Acta Chir. Scand. 141 786-789.

150. Mezey, E. \& Imbembo, A. L. (1978), Surgery 83; 345-353.

151. Danö, P., Nielsen, O. V., Petri, M. \& Jörgensen, B. (1976), Scand. J. Gastroenterol. 11, 129-134.

152. Iversen, B. M., Schjфnsby, H., Skagen, D. W. \& Solhaug, J. H. (1976), Europ. J. Clin. Invest. 6, 355-360.

153. Stein, T. A. \& Wise, L. (1978), Am. J. Clin. Nutrit. 31, 1143-1148.

154. Drenick, E. J., Ament, M. E., Finegold, S. M., Corrodi, P. \& Passaro, E. (1976), J. Am. Med. Ass. 236, 269-272.

Prof. Dr. Ellen Schmidt, F. W. Schmidt Abt. f. Gastroenterologie u. Hepatologie Med. Hochschule Hannover

Karl-Wiechert-Allee 9

D-3000. Hannover 61 